\title{
Targeted vaccination of teenagers following continued rapid endemic expansion of a single meningococcal group W clone (sequence type 11 clonal complex), United Kingdom 2015
}

H Campbell (helen.campbell@phe.gov.uk) ${ }^{1}$, V Saliba ${ }^{1}$, R Borrow $^{2}$, M Ramsay $^{1}$, S N Ladhani ${ }^{1}$

1. Public Health England, Immunisation Department, London, United Kingdom

2. Public Health England, Meningococcal Reference Unit, Manchester Royal Infirmary, Manchester, United Kingdom

Campbell H, Saliba V, Borrow R, Ramsay M, Ladhani SN. Targeted vaccination of teenagers following continued rapid endemic expansion of a single meningococcal group W clone (sequence type 11 clonal complex), United Kingdom 2015. Euro Surveill. 2015;20(28):pii=21188. Available online: http://www.eurosurveillance.org/ ViewArticle.aspx?Articleld $=21188$

Article submitted on 04 July 2015 / published on 16 July 2015

Since the epidemiological year 2009/10, the United Kingdom has experienced a year-on-year increase in meningococcal group $\mathrm{W}$ (MenW) disease due to rapid expansion of a single endemic hyper-virulent strain belonging to sequence type 11 clonal complex (cc). This strain was identified among cases diagnosed across all regions and was not linked to travel abroad. Consequently, an adolescent MenACWY conjugate vaccination programme for 13-18 year-olds will be introduced in August 2015, with priority given to 17-18 year-olds (school leavers).

Here we describe the epidemiology of invasive meningococcal disease and the emergence of a single meningococcal group W (MenW) clone in England in the last six years and the resulting public health measures.

\section{Background}

Neisseria meningitidis remains a major cause of meningitis and septicaemia worldwide [1]. While incidence varies by individual country and by age group, meningococcal group B (MenB) has been responsible for the majority of cases of invasive meningococcal disease (IMD) over the past decade in England (84\%) like in most European countries, where $74 \%$ of all IMD is due to MenB [2]. In England, meningococcal group $C$ (MenC) disease has been virtually eliminated following the introduction of the MenC conjugate vaccine into the national immunisation programme in 1999 [3].

Historically, MenW has been a rare cause of IMD in England, accounting for $<5 \%$ of all laboratory-confirmed cases $[4,5]$. An outbreak of invasive MenW disease following the Hajj (pilgrimage to Mecca) in the early 2000 s was soon controlled following mandatory MenACWY vaccination for all pilgrims [6]. In the 2008/09 epidemiological year (running from 1 July to 30 June the following year), MenW was responsible for only 19 of 1,109 (1.7\%) cases in England. Since then, however, MenW cases started to increase, with cases nearly doubling annually in recent years (Figure 1).

By end May 2015170 cases have already been confirmed for the epidemiological year 2014/15, compared with 88 and 46 cases for the same period in 2013/14 and $2012 / 13$, respectively. MenW is responsible for $25 \%$ of all IMD cases in England in 2014/15 to date, compared with $15 \%$ in $2013 / 14$ and $7 \%$ in $2012 / 13$. This increase has been accentuated by the concomitant decrease in MenB disease, which has been declining since $2000 / 01[4,5]$.

In England, the initial increase in MenW cases was seen in older adults, but soon extended across all age groups, especially adolescents (15-19 year-olds) and infants ( 1 year-olds) (Figure 2$)$.

Of the 26 MenW cases among 18-24 year-olds in 2014/15, 16 were attending higher education settings at the time. More recently, there has been a notable rise in cases among pre-school children (1-4 year-olds) from three to seven cases annually during 2009/10$2013 / 14$ to 18 by the end of May in 2014/15. The contribution of MenW to total IMD cases varied by age group, ranging from $49 \%$ in $\geq 65$ year-olds, to $32 \%$ in $15-19$ year-olds and $15 \%$ in $<5$ year-olds. This compares with $11 \%, 2 \%$ and $1 \%$ for the same age groups in England and Wales during 2007-11 [4].

\section{Clinical follow up of laboratory-confirmed meningococcal group $\mathrm{W}$ cases}

Clinical follow-up of 129 MenW cases diagnosed during 2010/11 to 2012/13 revealed that most MenW cases, especially children and young adults, were previously healthy ( $n=105 ; 81 \%$ ), and had not travelled abroad before illness, indicating that this strain is endemic and already established in carriage [5]. Half the MenW cases presented with septicaemia (49\%), followed by 


\section{FIGURE 1}

Cumulative number of laboratory-confirmed cases of invasive meningococcal group W (MenW) disease by epidemiological year, England, 2009/10-2014/15 (n=407)

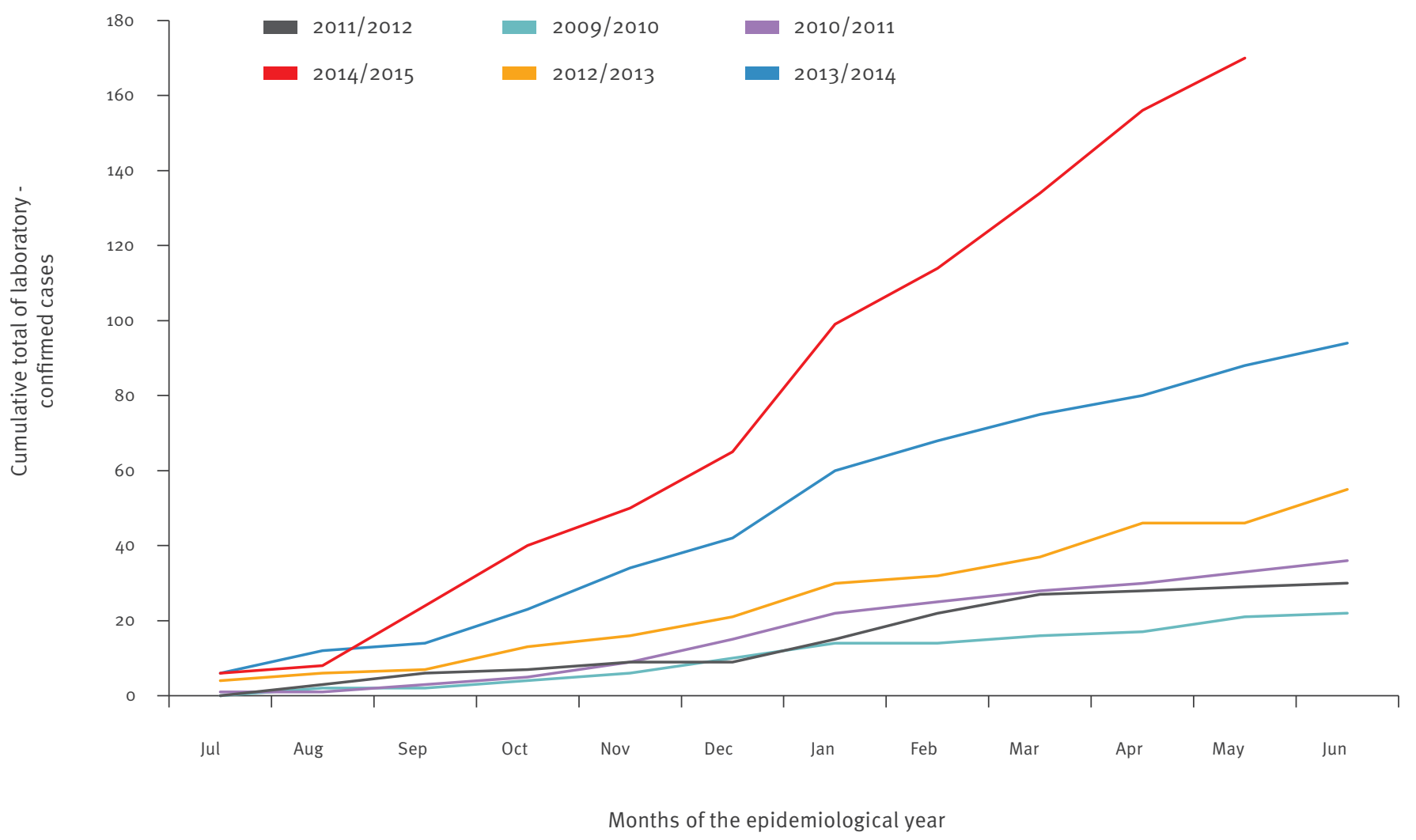

Data for the most recent epidemiological year (2014/15) are complete until end May 2015.

\section{FIGURE 2}

Age distribution of laboratory-confirmed cases of invasive meningococcal group W (MenW) disease by epidemiological year, England, 2009/10-2014/15 ( $\mathrm{n}=407)$

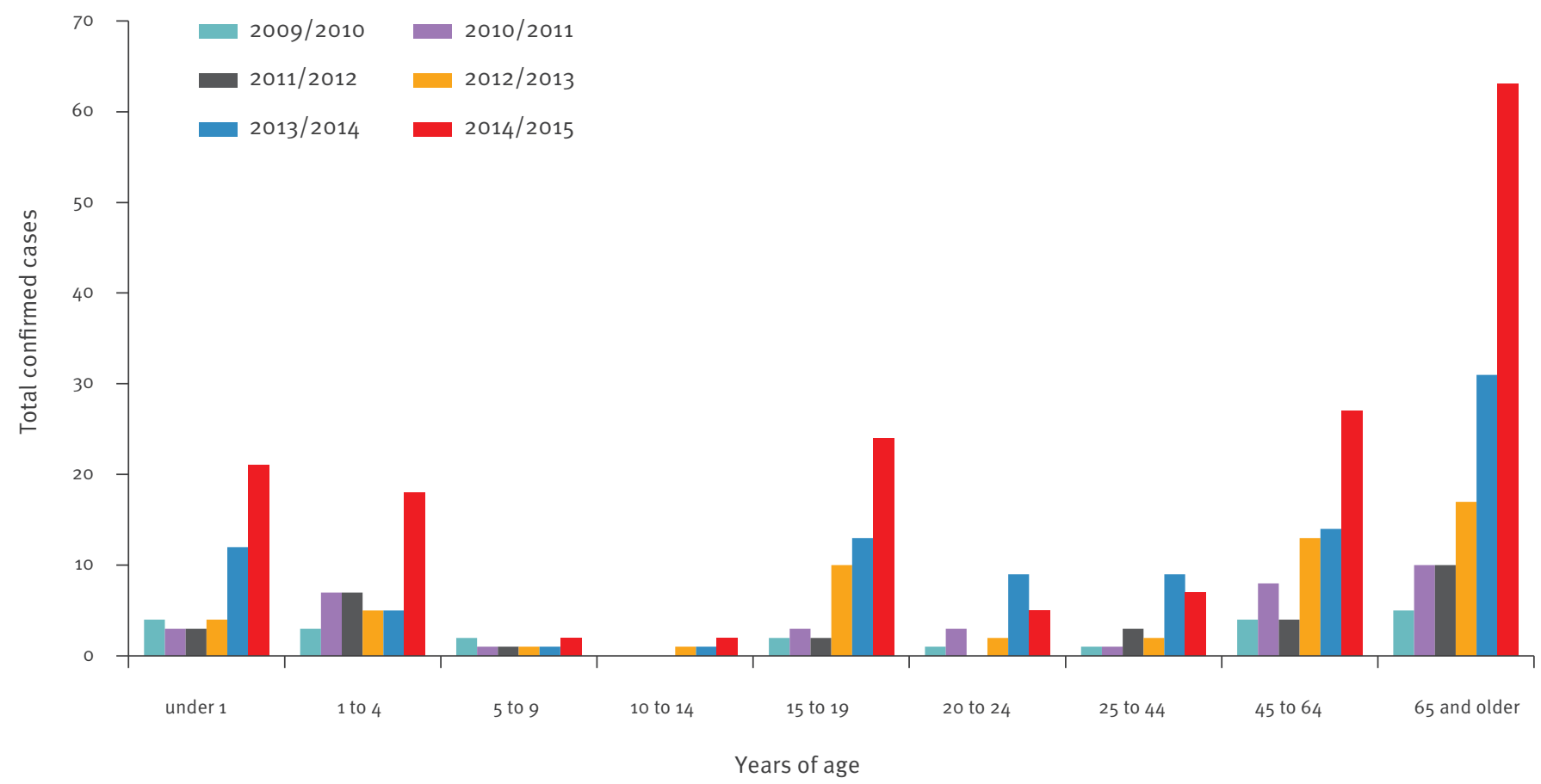

Data for the most recent epidemiological year (2014/15) are complete until end May 2015. 


\section{FIGURE 3}

Phenotypic characterisation of invasive clinical isolates of meningococcal group W (MenW) during A. Epidemiological year 2014/15 ( $n=170)$ and B. Epidemiological year 2008/09 $(n=19)$ in England

A. Epidemiological year $2014 / 15$

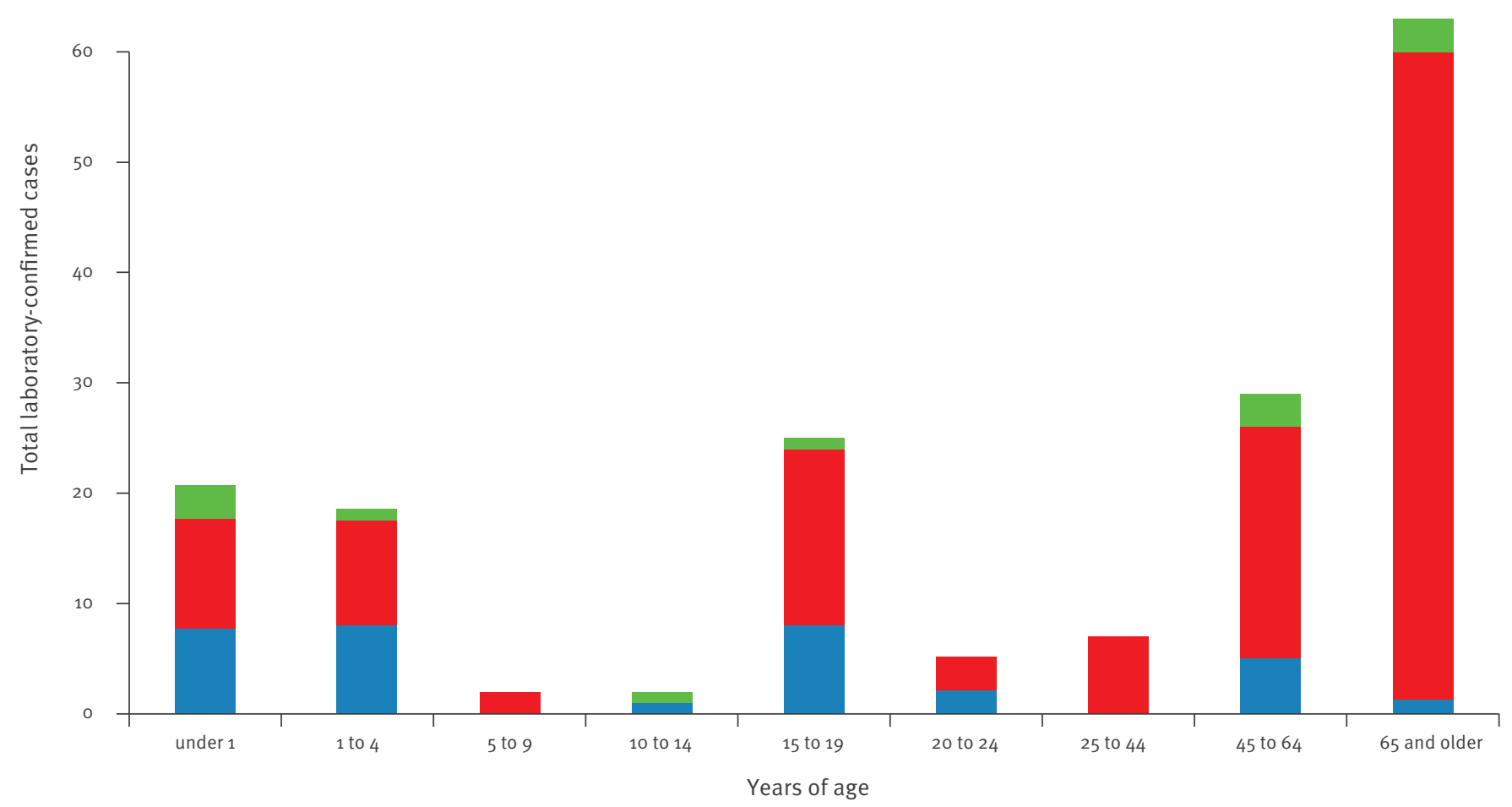

B. Epidemiological year 2008/09

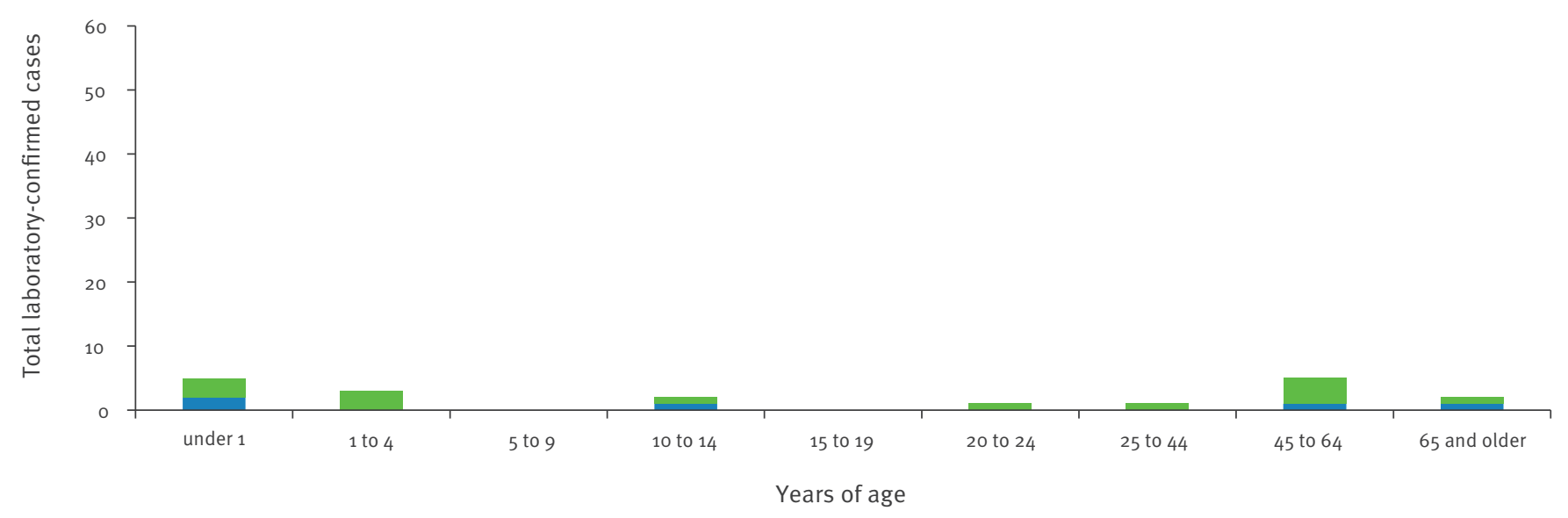


meningitis (12\%) or both (16\%), while a quarter had atypical presentations such as pneumonia (12\%), septic arthritis (7\%) and epiglottitis/supraglottitis (4\%). In $2014 / 15$, the MenW case fatality ratio was $12 \%$ (21/170 cases), consistent with previous years, and significantly higher than that reported for MenB [4]. Half the documented deaths were among $\geq 65$ year-olds and older (11 deaths), with six among 45-64 year-olds and two each among $18-30$ years and $<5$ year-olds.

\section{Characterisation of clinical meningococcal group $\mathrm{W}$ isolates}

MenW isolates from IMD cases have been phenotypically characterised as expressing PorB serotype $2 \mathrm{a}$, a surrogate marker for MenW:cc11 (Figure 3), and confirmed as belonging to cc11 by whole genome sequencing [5].

The increase in PCR-confirmed MenW cases is also most likely due to emergence of MenW: cc11. Comparison of whole genome sequences with a range of other strains belonging to cc11 has revealed the emerging MenW strain to be very similar to the one responsible for current South American outbreaks, $[7,8]$ which have been associated with very high case fatality rates [9].

\section{Public health action}

Because of the continuing rapid increase in MenW disease, the UK Joint Committee on Vaccination and Immunisation (JCVI) recommended vaccinating adolescents against MenACWY as a national emergency outbreak response to provide both direct and indirect (herd) protection [10]. This recommendation was accepted by the UK Departments of Health which, on 21 June 2015, announced the rapid introduction of an adolescent MenACWY conjugate vaccine programme to begin in August 2015. The programme will target 13-18 year-olds, the age group at increased risk of IMD and with the highest meningococcal carriage rates $[11,12]$. Adolescents aged $17-18$ years (current school year 13) will be the first group to be offered the vaccine, from August 2015, in order to prioritise those leaving school and entering higher education in the next academic year. A time-limited Freshers' programme offering the MenACWY conjugate vaccine to unvaccinated university entrants up to 25 years of age will also be in place. The adolescent MenC conjugate vaccine currently recommended for 13-14 year-olds will be replaced with the MenACWY conjugate vaccine. Over the next two years, all remaining adolescents in the 13-18 year age groups will be offered MenACWY conjugate vaccine. In addition to providing adolescents with direct protection against these capsular groups, it is expected that, by reducing carriage in individuals with high meningococcal carriage rates [12], all other age groups will be protected indirectly over the coming years. Full details of the adolescent MenACWY vaccination programme can be found on the PHE website [13].

\section{Implications for other countries}

The rapid introduction of a MenACWY conjugate vaccination programme in the UK will provide direct protection for adolescents at the time when they are most vulnerable to IMD and, is expected consequently, to contribute to indirect (herd) protection by interrupting transmission through carriage prevention. So far, no other European country has reported an endemic increase in invasive MenW disease. In France, six epidemiologically- and geographically-unlinked MenW cases were diagnosed in the first three months of 2012 [14]. Unlike the situation in the UK, all cases were associated with recent travel by the patient or patient contacts to sub-Saharan Africa, where large multinational outbreaks of MenW:cc11 were occurring at the time. Given how quickly this hypervirulent MenW:cc11 clone has established itself in populations across different continents [8], European countries should remain highly vigilant and be prepared to control this aggressive but vaccine-preventable infection.

\section{Acknowledgements}

We would like to acknowledge the hard work of the surveillance team at PHE Colindale, the laboratory staff at PHE MRU and the Local Health Protection Teams. In particular we would like to thank Sonia Ribeiro, Tracey Leech, Kazim Beebeejaun, Steve Gray and Jay Lucidarme.

\section{Conflict of interest}

The Public Health England (PHE) Immunisation Department has provided vaccine manufactures with post-marketing surveillance reports which the marketing authorisation holders are required to submit to the UK licensing authority in compliance with their risk management strategy. A cost recovery charge is made for these reports. RB performs contract research on behalf of PHE for GSK, Novartis, Pfizer, Sanofi Pasteur and Sanofi Pasteur MSD.

\section{Authors' contributions}

The Immunisation Department (HC, VS, MR, SL) and the Meningococcal Reference Unit (RB) at Public Health England conduct enhanced national surveillance of meningococcal disease in England. All authors have contributed equally to writing and commenting on the draft manuscript. All authors have seen and approved the final manuscript.

References

1. Harrison LH, Trotter CL, Ramsay ME. Global epidemiology of meningococcal disease. Vaccine. 2009;27(Suppl 2):B5163. http://dx.doi.org/10.1016/j.vaccine.2009.04.063 PMID:19477562

2. European Centre for Disease Prevention and Control. Surveillance of invasive bacterial diseases in Europe, 2011. Stockholm: ECDC; 2013. Available from: http://ecdc.europa. eu/en/publications/Publications/invasive-bacterial-diseasessurveillance-2011.pdf

3. Campbell H, Andrews N, Borrow R, Trotter C, Miller E. Updated postlicensure surveillance of the meningococcal $C$ conjugate vaccine in England and Wales: effectiveness, validation of serological correlates of protection, and modeling predictions of the duration of herd immunity. Clin Vaccine Immunol. 2010;17(5):840-7. http://dx.doi.org/10.1128/CVI.00529-09 PMID:20219881 
4. Ladhani SN, Flood JS, Ramsay ME, Campbell H, Gray SJ, Kaczmarski EB, et al. Invasive meningococcal disease in England and Wales: implications for the introduction of new vaccines. Vaccine. 2012;30(24):3710-6. http://dx.doi. org/10.1016/j.vaccine.2012.03.011 PMID:22429756

5. Ladhani SN, Beebeejaun K, Lucidarme J, Campbell H, Gray $\mathrm{S}$, Kaczmarski E, et al. Increase in endemic Neisseria meningitidis capsular group W ST-11 complex associated with severe invasive disease in England and Wales. Clin Infect Dis.2015;60(4):578-85.

6. Hahné SJ, Gray SJ, Aguilera JF, Crowcroft NS, Nichols T, et al. W135 meningococcal disease in England and Wales associated with Hajj 2000 and 2001. Lancet. 2002;359(9306):582 3. http://dx.doi.org/10.1016/S0140-6736(02)07716-4 PMID:11867116

7. Abad R, López EL, Debbag R, Vázquez JA. Serogroup $W$ meningococcal disease: global spread and current affect on the Southern Cone in Latin America. Epidemiol Infect. 2014;142(12):2461-70. http://dx.doi.org/10.1017/ So950268814001149 PMID:24831052

8. Lucidarme J, Hill DM, Bratcher HB, Gray SJ, du Plessis M, Tsang RS, et al. Geo-temporal distribution of distinct strains of the hyperinvasive meningococcal ST-11 clonal complex. J Infect. 2015. Forthcoming.

9. Araya P, Fernández J, Del Canto F, Seoane M, Ibarz-Pavón AB, Barra G, et al. Neisseria meningitidis ST-11 clonal complex, Chile 2012. Emerg Infect Dis. 2015;21(2):339-41. http://dx.doi. org/10.3201/eid2102.140746 PMID:25625322

10. Public Health England (PHE). The Joint Committee on Vaccination and Immunisation (JCVI). The JCVI has today (13 March 2015) advised that immunisation for meningococcal group W (MenW) disease be offered to 14 to 18 year-olds. 2015 Mar 13. Press release. Available from: https://www. gov.uk/government/news/meningococcal-group-w-menwimmunisation-advised-for-14-to-18-year-olds

11. Jeppesen CA, Snape MD, Robinson H, Gossger N, John TM, Voysey $M$, et al. Meningococcal carriage in adolescents in the United Kingdom to inform timing of an adolescent vaccination strategy. J Infect. 2015;71(1):43-52. http://dx.doi.org/10.1016/j. jinf.2015.02.006 PMID:25709085

12. Christensen H, May M, Bowen L, Hickman M, Trotter CL. Meningococcal carriage by age: a systematic review and metaanalysis. Lancet Infect Dis. 2010;10(12):853-61. http://dx.doi. org/10.1016/S1473-3099(10)70251-6 PMID:21075057

13. Public Health England (PHE). Immunisation information for health professionals and immunisation practitioners. London: PHE; 2013. Available from: https://www.gov.uk/government/ collections/immunisation.

14. Taha MK, Kacou-N'douba A, Hong E, Deghmane AE, Giorgini D, Okpo SL, et al. Travel-related Neisseria meningitidis serogroup W135 infection, France. Emerg Infect Dis. 2013;19(6):1030-2. http://dx.doi.org/10.3201/eid1906.120515 PMID:23735310 